\title{
Ion Chromatographic Determination of Sodium, Potassium, Magnesium and Calcium Ions in River Water
}

\author{
Tadashi IwaChIDo*, Mitsuyoshi ShInomiYA** and Michio ZENKI** \\ *College of Liberal Arts, Okayama University, Tsushima, Okayama 700, Japan \\ ** Department of Chemistry, Faculty of Science, Okayama University of Science, \\ Ridai-cho, Okayama 700, Japan
}

\begin{abstract}
The factors affecting the ion chromatographic separation of the alkaline earth metal cations on silica gel columns were investigated using different types of dicarboxylic acids as retention modifiers. The mobile phase pH and acid concentration showed marked influence on the separation of the analytes. When a $0.002 \mathrm{~mol} \mathrm{dm}^{-3}$ lithium oxalate solution of $\mathrm{pH} 7$ was used as a mobile phase, the major four cations in river water $\left(\mathrm{Na}^{+}, \mathrm{K}^{+}, \mathrm{Mg}^{2+}\right.$ and $\left.\mathrm{Ca}^{2+}\right)$ were completely separated on a Nucleosil column $(50 \mathrm{~mm} \times 4.6 \mathrm{~mm}$ i.d.) within about $16 \mathrm{~min}$.
\end{abstract}

Keywords Silica gel column, ion chromatography, alkaline earth cations, sodium, potassium, magnesium, calcium, oxalic acid, river water

Silica gel is obtained mechanically as stable porous microparticles, the pore size being easily controllable. Though the surface shows a polar nature due to the silanol group, the polarity can easily be altered by introducing a nonpolar substance on the surface through chemical bonding. Such properties of silica gel fulfill the requirements for a stationary phase. For this reason, silica gel has widely been used in an unmodified or modified state in several modes of liquid chromatography. ${ }^{1}$

On the other hand, unmodified silica gel is known to function as an ion exchanger. However, the analytical applications of silica gel to column chromatography are not so popular as those of resin-based ion exchangers. Of course, little is known about its applications to newly developed ion chromatography (IC).2,3 Recently, Smith and Pietrzyk ${ }^{4}$ revealed that many inorganic cations were separable on an unmodified silica gel column by means of IC. In a previous paper ${ }^{5}$, we also demonstrated that such an IC method was successfully applicable to the determination of $\mathrm{Na}^{+}$and $\mathrm{K}^{+}$in river water.

This work describes that a silica gel-oxalate IC system is successful for the determination of $\mathrm{Na}^{+}, \mathrm{K}^{+}$, $\mathrm{Mg}^{2+}$ and $\mathrm{Ca}^{2+}$ in river water.

\section{Experimental}

\section{Reagents}

Alkali metal chlorides of reagent grade (Merck) were used as received. Alkaline earth metal chlorides (Wako) of reagent grade were made into $1 \times 10^{-2} \mathrm{~mol} \mathrm{dm}^{-3}$ aqueous solutions and used as test analytes. Dicarboxylic acids (oxalic, malonic, tartronic, ketomalonic, malic, succinic and tartaric acids; Tokyo Kasei) were used without further purification. These acids were also made into $1 \times 10^{-2} \mathrm{~mol} \mathrm{dm}^{-3}$ aqueous solutions, the $\mathrm{pH}$ being adjusted by adding a lithium hydroxide solution. Water was prepared by the successive use of an Auto Still (WAG-28, Yamato) and an all-quartz-made, nonboiling type distilling apparatus (HF-200, Fujiwara). The ligands and the test analytes were dissolved into the water, thus obtained, and the resulting solutions were then filtered through a membrane filter (pore size $=0.22$ $\mu \mathrm{m}$, Millipore) prior to use.

\section{Columns}

Spherical Nucleosil (pore size $=50 \AA$, particle size $=5$ $\mu \mathrm{m}$; Nagel) was used as an ion exchanger. These were made into slurries using a slurry mix (NP type, Chemco) under the irradiation of ultrasonic waves and then pumped into stainless-steel columns of different size $((50-150) \mathrm{mm} \times 4.6 \mathrm{~mm}$ i.d.) by using a slurry packer (Model 124, Chemco).

\section{Apparatus and procedure}

The apparatus used was an assembly of a solvent delivery pump (LC6A, Shimadzu), a syringe-loading sample-injection valve (Model 7125, Rheodyne) equipped with a $200-\mu l\left(1 \mathrm{l}=1 \mathrm{dm}^{3}\right)$ sample loop, a conductometer (Model 701, LDC), an integrator (Model 3390A, Hewlett-Packard) and a pen recorder (Model 056, Hitachi). Sample solutions of 5 or $10 \mu$ l portions were injected by using a $10-\mu$ l microsyringe (Hamilton); river-water samples were injected in $200-\mu l$ portions 
through the sample loop. The flow rates of the mobile phases were varied from 1.0 to $1.5 \mathrm{ml} / \mathrm{min}$, depending upon the column sizes used; the operating pressures never exceeded $80 \mathrm{~kg} \mathrm{~cm}^{-2}$. The temperature of the IC system was controlled at $(25 \pm 0.1)^{\circ} \mathrm{C}$.

$\mathrm{Na}^{+}$and $\mathrm{K}^{+}$in river water were also determined with a polarized Zeeman atomic absorption spectrophotometer (Model Z-8000, Hitachi). $\mathrm{Mg}^{2+}$ and $\mathrm{Ca}^{2+}$ were determined by means of a chelatometric titration method. ${ }^{6}$

\section{Results and Discussion}

\section{Conductivity detector response}

Consider an IC system consisting of silica gel and a mobile phase of $\mathrm{pH} 7$ containing $\mathrm{Li}_{2} \mathrm{Ox}$ as a mobilephase electrolyte. The $\mathrm{p} K_{\mathrm{a}}(-\mathrm{SiOH})$ of silica gel is estimated to be 7.1.7 At this $\mathrm{pH}$ about half of the silanol sites can function as cation-exchange sites, $-\mathrm{SiO}^{-}$. The following ion-exchange equilibrium is valid in understanding the detector response:

$$
\begin{aligned}
& (-\mathrm{SiO})_{2} \mathrm{M}+2 \mathrm{Li}^{+} \rightleftharpoons 2(-\mathrm{SiOLi})+\mathrm{M}^{2+} \\
& \mathrm{M}^{2+}+\mathrm{Ox}^{2-} \rightleftharpoons \mathrm{MOx} .
\end{aligned}
$$

The conductance of a column effluent without containing $\mathrm{M}^{2+}$ (background conductance, $G_{\mathrm{B}}$, in $\mu \mathrm{S}$ unit) is given by

$$
G_{\mathrm{B}}=\left(\lambda_{\mathrm{Li}}+\lambda_{\mathrm{Ox}}\right) C_{\mathrm{E}} I_{\mathrm{E}} /\left(10^{-3} \mathrm{~K}\right)
$$

where $\lambda$ is the limiting equivalent conductance, $C_{\mathrm{E}}$ and $I_{\mathrm{E}}$ are the concentration and the ionized fraction of the eluent electrolyte respectively, and $K$ is the cell constant.

Sample cations, $\mathrm{M}^{2+}$, which are displaced by an equivalent amount of eluent cations, $\mathrm{Li}^{+}$, partly recombine with eluent anions to give complexes, MOx. It follows that the decrease in the eluent concentration is equal to the total concentration of the displaced cations, $C_{\mathrm{M}}\left(=\left[\mathrm{M}^{2+}\right]+[\mathrm{MOx}]\right)$. The displaced cations also contribute to the conductivity. Hence, the conductance of a column effluent containing $\mathrm{M}^{2+}$ is given by ${ }^{8}$

$$
G_{\mathrm{M}}=\left[\left(\lambda_{\mathrm{Li}}+\lambda_{\mathrm{Ox}}\right)\left(C_{\mathrm{E}}-C_{\mathrm{M}}\right) I_{\mathrm{E}}+\left(\lambda_{\mathrm{M}}+\lambda_{\mathrm{Ox}}\right) C_{\mathrm{M}} I_{\mathrm{M}}\right] /\left(10^{-3} K\right),
$$

where $C_{\mathrm{M}}$ and $I_{\mathrm{M}}$ refer to the concentration and the ionized fraction of the sample species in the detector cell.

Substituting Eq. (3) from Eq. (4) yields

$$
\Delta G=\left[\left(\lambda_{\mathrm{M}}+\lambda_{\mathrm{Ox}}\right) I_{\mathrm{M}}-\left(\lambda_{\mathrm{Li}}+\lambda_{\mathrm{Ox}}\right) I_{\mathrm{E}}\right] C_{\mathrm{M}} /\left(10^{-3} K\right),
$$

where $\Delta G$ represents the conductivity deviation from the base-line conductivity. Since $C_{\mathrm{M}}$ will follow an approximately Gaussian profile and $I_{M}$ and $I_{E}$ are approximately kept constant during sample elution, the detector response will also follow a Gaussian profile.

Since $\mathrm{Ox}^{2-}$ is considered to form a complex with $\mathrm{M}^{2+}$, but does not with $\mathrm{Li}^{+}\left(I_{\mathrm{E}}=1\right)$, Eq. (5) is simplified to

$$
\Delta G=\left[\left(\lambda_{\mathrm{M}}+\lambda_{\mathrm{Ox}}\right) I_{\mathrm{M}}-\left(\lambda_{\mathrm{Li}}+\lambda_{\mathrm{Ox}}\right)\right] C_{\mathrm{M}} /\left(10^{-3} K\right) .
$$

The direction of a chromatographic peak can be predicted by means of the $I_{M}$ values calculated from the stability constants, $K_{\mathrm{MO}}$, in the following manner:

$$
K_{\mathrm{MOx}}=[\mathrm{MOx}] /\left(\left[\mathrm{M}^{2+}\right]\left[\mathrm{Ox}^{2-}\right]\right),
$$

where the brackets refer to the molar concentration. Taking into account that $C_{\mathrm{M}} \ll C_{\mathrm{E}}$, we have

$$
I_{\mathrm{M}}=1 /\left(K_{\mathrm{MOX}} C_{\mathrm{E}}+1\right) \text {. }
$$

Substituting Eq. (8) in Eq. (6), we have

$$
\Delta G=\left[\left(\lambda_{\mathrm{M}}+\lambda_{\mathrm{Ox}}\right) /\left(K_{\mathrm{MOx}} C_{\mathrm{E}}+1\right)-\left(\lambda_{\mathrm{Li}}+\lambda_{\mathrm{Ox}}\right)\right] C_{\mathrm{M}} /\left(10^{-3} K\right) .
$$

The chromatographic peaks for the alkaline earth metal complexes with dicarboxylate ions, ML, are all negative, as shown in Fig. 1. The signs of most $\Delta G$ values calculated by means of $\lambda$ (Table 1 ) and the $K_{\mathrm{ML}}$

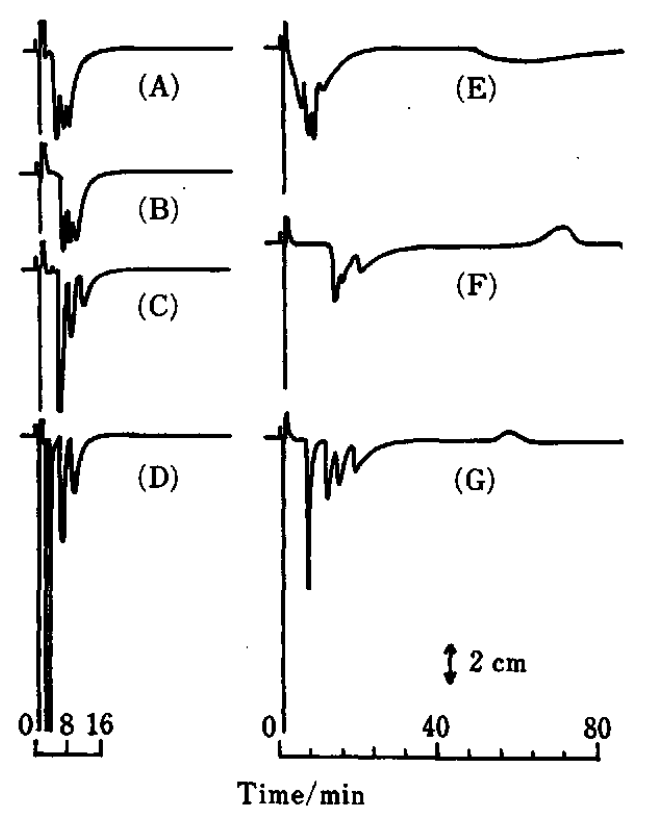

Fig. 1 Chromatograms of an alkaline earth metal $\left(\mathrm{Mg}^{2+}, \mathrm{Ca}^{2+}\right.$, $\mathrm{Sr}^{2+}$ and $\mathrm{Ba}^{2+}$ ) chlorides obtained with dicarboxylate anions as the mobile phase ligands. A $5 \mu$ l portion of the analyte solution $\left(0.01 \mathrm{M}\left(1 \mathrm{M}=1 \mathrm{~mol} \mathrm{dm}^{-3}\right)\right)$ was chromatographed on a $100 \mathrm{~mm} \times 4.6 \mathrm{~mm}$ i.d. Nucleosil column using $0.01 \mathrm{M}$ ketomalonate (A), tartarate (B), tartronate (C), oxalate (D), malate $(E)$, succinate $(F)$ and malonate $(G)$ mobile phases of pH 7 at a flow rate $1.0 \mathrm{ml} / \mathrm{min}$; detector, $0.1 \times 10^{-2} \mu \mathrm{S} / \mathrm{cm}$ (output: $10 \mathrm{mV}$ ); recorder, $10 \mathrm{mV} / 20 \mathrm{~cm}$ (FS). 
Table 1 The limiting equivalent conductances of cations at $25^{\circ} \mathrm{C}$ in water ${ }^{8}$

\begin{tabular}{llllll}
\hline \multicolumn{5}{c}{$\lambda / \mathrm{S} \mathrm{cm}^{2}$ equiv } & \\
\hline $\mathrm{Li}^{+}$ & 38.7 & $\mathrm{Mg}^{2+}$ & 53.1 & $\mathrm{NH}_{4}{ }^{+}$ & 73.6 \\
$\mathrm{Na}^{+}$ & 50.1 & $\mathrm{Ca}^{2+}$ & 59.5 & $\mathrm{Ox}^{2-}$ & 74.2 \\
$\mathrm{~K}^{+}$ & 73.5 & $\mathrm{Sr}^{2+}$ & 59.5 & & \\
$\mathrm{Rb}^{+}$ & 77.8 & $\mathrm{Ba}^{2+}$ & 63.6 & & \\
$\mathrm{Cs}^{+}$ & 77.3 & & & &
\end{tabular}

$\mathrm{Ox}^{2-}$, oxalate ion.

(Table 2) values were negative, as expected. However, for some unstable complexes, the calculated $\Delta G$ values were positive. One of the causes of such a discordance is that the $K_{\mathrm{ML}}$ and $\lambda$ values obtained under ionic strengths different from the chromatographic conditions were used for the calculation.

If it is assumed that $I_{\mathrm{M}}=1$ and $I_{\mathrm{E}}=1$, then

$$
\Delta G=\left(\lambda_{\mathrm{M}}-\lambda_{\mathrm{Ox}}\right) C_{\mathrm{M}} /\left(10^{-3} K\right)
$$

In an alkali metal cation-ligand system, it is assumed that $I_{\mathrm{M}}=1$ and $\lambda_{\mathrm{M}}>\lambda_{\mathrm{Li}}$. This fact implies that positive peaks will result. As can be seen from Fig. 5, positive peaks were observed for $\mathrm{Na}^{+}$and $\mathrm{K}^{+}$.

\section{Retention of the analyte cations}

Strazhesko et al. ${ }^{2}$ reported that the alkaline earth metal cations are strongly retained on unmodified silica gel and that their retention times increase in the following order:

$$
\mathrm{Mg}^{2+}<\mathrm{Ca}^{2+}<\mathrm{Sr}^{2+}<\mathrm{Ba}^{2+}
$$

Dicarboxylate anion, $\mathrm{L}^{2-}$, reacts with $\mathrm{M}^{2+}$ to form relatively stable complex, ML, where

$$
\mathrm{M}^{2+}+\mathrm{L}^{2-} \rightleftharpoons \mathrm{ML}
$$

and

$$
K_{\mathrm{ML}}=[\mathrm{ML}] /\left(\left[\mathrm{M}^{2+}\right]\left[\mathrm{L}^{2-}\right]\right)
$$

Electrically neutral ML has virtually no interactions with the exchange sites and is retained very weakly by means of the van der Waals force. Analyte retention is governed by the relative amounts of $\mathrm{M}^{2+}$ and $\mathrm{ML}$. From these facts, it can be estimated that the use of $L$, which combines strongly with the analyte cation, shortens to a great extent the retention times of the analytes.

\section{Chromatograms}

Typical chromatograms obtained with a mixture of $\mathrm{Mg}^{2+}, \mathrm{Ca}^{2+}, \mathrm{Sr}^{2+}$ and $\mathrm{Ba}^{2+}$ on a silica gel column $(100 \mathrm{~mm} \times 4.6 \mathrm{~mm}$ i.d.) using mobile phases ( $[\mathrm{L}]=0.01$ mol $\mathrm{dm}^{-3}$ ) of $\mathrm{pH} 7$ at a flow rate of $1 \mathrm{ml} \mathrm{min}^{-1}$ are shown in Fig. 1. Judging from the $\mathrm{p} K_{2}$ values
(Table 2), the ligands used exist almost completely as $\mathrm{L}^{2-}$ at $\mathrm{pH} 7$.

The complete separation of the individual cations was attained with the oxalate and the malonate mobile phases alone. It was estimated that the first negative peaks are due to water contained in the analyte solution, and the second positive peaks are due to the counter anion of the analyte. The next three or four negative peaks were assigned to analyte peaks based on the their retention times. The observed retention sequences can be summarized as follows:

$$
\begin{array}{cl}
\text { Retention sequence } & \multicolumn{1}{c}{\text { Mobile phase }} \\
\mathrm{Mg}^{2+}<\mathrm{Ca}^{2+}<\mathrm{Sr}^{2+}<\mathrm{Ba}^{2+} & \text { oxalate, malonate } \\
\mathrm{Mg}^{2+}=\mathrm{Ca}^{2+}<\mathrm{Sr}^{2+}<\mathrm{Ba}^{2+} & \text { succinate, tartronate } \\
\mathrm{Ca}^{2+}<\mathrm{Mg}^{2+}=\mathrm{Sr}^{2+}<\mathrm{Ba}^{2+} & \text { malate } \\
\mathrm{Ca}^{2+}<\mathrm{Sr}^{2+}<\mathrm{Mg}^{2+}=\mathrm{Ba}^{2+} & \text { tartarate, ketomalonate }
\end{array}
$$

Though the order of $\mathrm{Mg}^{2+}$ varied widely from ligand to ligand, the following sequence was found in common:

$$
\mathrm{Ca}^{2+}<\mathrm{Sr}^{2+}<\mathrm{Ba}^{2+}
$$

As can be seen from Fig. 1, the oxalate and the malonate mobile phases were satisfactory for the separation of the analytes. In the chromatogram of malonate (malate and succinate as well), however, a late eluting unidentified peak was observed. The occurrence of such a peak was disadvantageous for a rapid determination. Hence, the oxalate was thereafter used as the mobile phase ligand.

\section{Eluting power of the ligands}

In Fig. 2, log-log plots of $K_{\mathrm{ML}} v s . k^{\prime}$ (capacity factor) are shown. Straight lines were observed for all the

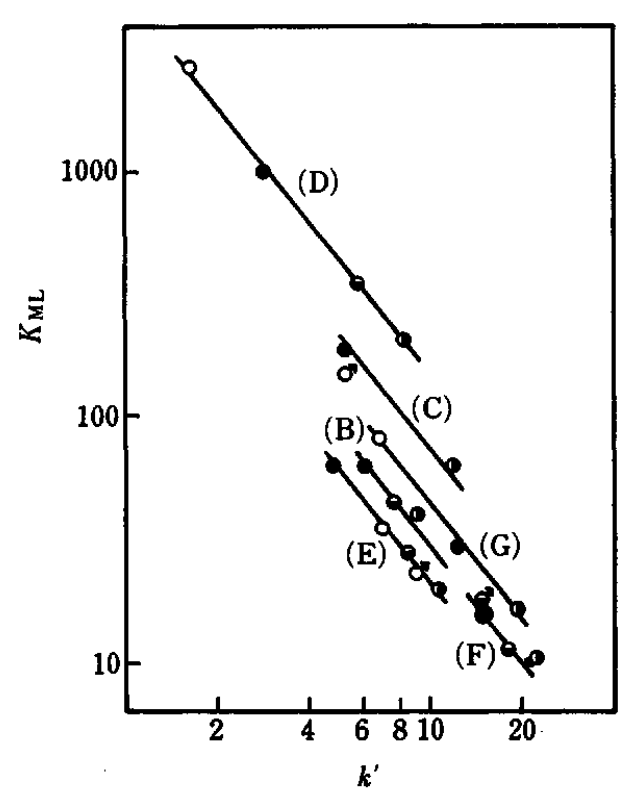

Fig. 2 Log-log plots of $K_{\mathrm{ML}} v s . \boldsymbol{k}^{\prime}$ (capacity factor). $\bigcirc, \mathrm{Mg}^{2+}$; , $\mathrm{Ca}^{2+} ; \Theta, \mathrm{Sr}^{2+} ; \ominus, \mathrm{Ba}^{2+} ;$ other conditions, see Fig. 1. 
Table 2 Retention times, $t_{\mathrm{R}}$, and stability constants, $\log K_{\mathrm{ML}}$

\begin{tabular}{|c|c|c|c|c|c|c|c|}
\hline Ligand & $\mathrm{p} K_{1}$ & $\mathrm{p} K_{2}$ & & $\mathrm{Mg}^{2+}$ & $\mathrm{Ca}^{2+}$ & $\mathrm{Sr}^{2+}$ & $\mathrm{Ba}^{2+}$ \\
\hline \multirow[t]{2}{*}{ Oxalate } & $1.25^{\mathrm{a}}$ & $4.29^{\mathrm{a}}$ & $\log K_{\mathrm{ML}}$ & $3.43^{\mathrm{g}}$ & $3.00^{\mathrm{h}}$ & $2.54^{\mathrm{h}}$ & $2.31^{b}$ \\
\hline & & & $t_{\mathrm{R}}$ & 2.32 & 3.33 & 5.93 & 7.89 \\
\hline \multirow[t]{2}{*}{ Malonate } & $2.85^{\mathrm{b}}$ & $5.67^{\mathrm{b}}$ & $\log K_{\mathrm{ML}^{\mathrm{i}}}$ & 1.91 & 1.46 & 1.25 & 1.23 \\
\hline & & & $t_{\mathrm{R}}$ & 6.84 & 11.3 & 13.7 & 17.5 \\
\hline \multirow[t]{2}{*}{ Tartronate } & $2.02^{\mathrm{c}}$ & $4.24^{\mathrm{c}}$ & $\log K_{\mathrm{ML}}^{\mathrm{c}}$ & 2.17 & 2.27 & - & 1.80 \\
\hline & & & $t_{\mathrm{R}}$ & 5.47 & 5.47 & 7.99 & 11.0 \\
\hline \multirow[t]{2}{*}{ Ketomalonate } & - & - & $\log K_{\mathrm{ML}}$ & - & - & - & - \\
\hline & & & $t_{\mathrm{R}}$ & 7.66 & 5.03 & 6.43 & 7.66 \\
\hline \multirow[t]{2}{*}{ Succinate } & $4.21^{\mathrm{d}}$ & $5.64^{d}$ & $\log K_{M L^{i}}$ & 1.20 & 1.20 & 1.06 & 1.03 \\
\hline & & & $t_{\mathrm{R}}$ & 13.9 & 13.9 & 15.9 & 20.4 \\
\hline \multirow[t]{2}{*}{ Malate } & $3.46^{\mathrm{e}}$ & $5.10^{\mathrm{e}}$ & $\log K_{M L^{i}}$ & 1.55 & 1.80 & 1.45 & 1.30 \\
\hline & & & $t_{\mathrm{R}}$ & 6.86 & 5.00 & 8.06 & 10.1 \\
\hline \multirow{2}{*}{ Tartarate } & $3.04^{\mathrm{f}}$ & $4.37^{\mathrm{f}}$ & $\log K_{M L}{ }^{i}$ & 1.36 & 1.80 & 1.65 & 1.62 \\
\hline & & & $t_{\mathrm{R}}$ & 8.59 & 6.11 & 7.42 & 8.59 \\
\hline
\end{tabular}

a. ref. 11 (medium $\rightarrow 0 \mathrm{M}$ ); b. ref. 12 (medium $\rightarrow 0 \mathrm{M}$ ); c. ref. 13 (medium $\rightarrow 0 \mathrm{M}$ (pK $K_{1}$ and $\mathrm{p} K_{2}$ ), $0.1 \mathrm{M} \mathrm{NaClO}_{4}$ ); d. ref. 14 (medium $\rightarrow 0 \mathrm{M}$ ); e. ref. 15 (medium $\rightarrow 0 \mathrm{M}$ ); f. ref. 16 (medium $\rightarrow 0 \mathrm{M}$ ); g. ref. 17 (medium $\rightarrow 0 \mathrm{M}$ ); h. ref. 18 (medium $\rightarrow 0 \mathrm{M}$ ); i. ref. 19 (medium $0.2 \mathrm{M}$ ).

ligands, the slopes being the same for the ligands. Assuming that the analyte retention depends on $K_{\mathrm{ML}}$ alone, all of the points are expected to fall on a single line. Let us superpose such an imaginary straight line upon the oxalate line as a matter of convenience. The distances, parallel to the horizontal axis, from the imaginary line to the individual lines increased in the following order:

oxalate $<$ tartronate $<$ malonate $<$ tartarate $=$ succinate $<$ malate.

A somewhat different sequence was observed with Zorbax SIL (Du Pont) reflecting subtle distinction of the surface properties between the two types of silica gels:

oxalate $<$ tartarate $<$ malate $<$ malonate $<$ succinate.

Such an eluting power may exhibit a rough correlation with the ligand structure; i.e., an increase in the number of $-\mathrm{CH}_{2-}$ groups tends to increase the eluting power, while an increase in the number of $-\mathrm{OH}$ groups tends to decrease the eluting power.

\section{pH of mobile phase}

In the IC system, some weak acids were concerned. The $\mathrm{p} K_{\mathrm{a}}$ value of $-\mathrm{SiOH}$ is 7.1 , as mentioned. The hydrolysis constants, $\mathrm{p} K_{11}$, defined for such reaction as $\left.\mathrm{M}^{2+}+\mathrm{H}_{2} \mathrm{O}\right) \rightleftharpoons \mathrm{M}(\mathrm{OH})^{+}+\mathrm{H}^{+}$are 11.44, 12.85, 13.29 and 13.47 for $\mathrm{Mg}^{2+}, \mathrm{Ca}^{2+}, \mathrm{Sr}^{2+}$ and $\mathrm{Ba}^{2+}$, respectively. ${ }^{10}$ The $\mathrm{p} K_{2}$ value of $\mathrm{H}_{2} \mathrm{OX}$ is $4.29^{11}$ (Table 2).

It is estimated from the $\mathrm{p} K$ values that alkaline media ranging from $\mathrm{pH} 7$ to $\mathrm{pH} 10$ are favored because, under such conditions, $-\mathrm{Si}(\mathrm{OH})$ and $\mathrm{H}_{2} \mathrm{Ox}$ exist as $-\mathrm{SiO}^{-}$and $\mathrm{Ox}^{2-}$ and the formation of hydrolyzed cations, such as

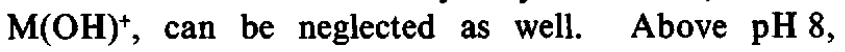

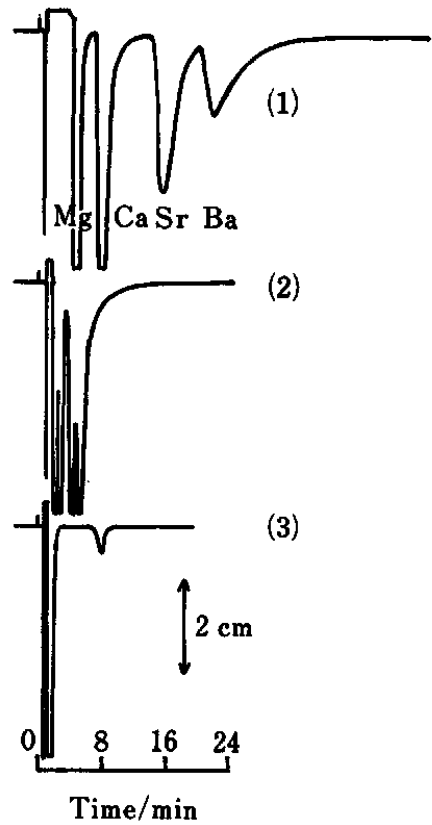

Fig. 3 Effect of $\mathrm{pH}$ on the retention time of the test analyte. Mobile phase: $7.5 \times 10^{-3} \mathrm{M}$ oxalate solution, (1) $\mathrm{pH} 7,(2) \mathrm{pH} 6$ and (3) $\mathrm{pH} 5$; other conditions, see Fig. 1.

however, it is estimated that the dissolution of the silica gel becomes more and more conspicuous. For this reason, weakly acidic media ranging from $\mathrm{pH} 5$ to $\mathrm{pH} 7$ were investigated at a cost of a decrease of $-\mathrm{SiO}^{-}$sites.

The obtained chromatograms are shown in Fig. 3. The peak resolution became poorer as the mobile phase $\mathrm{pH}$ decreased, reflecting a decreased number of $-\mathrm{SiO}^{-}$sites. In the chromatogram of $\mathrm{pH} \mathrm{5,} \mathrm{no} \mathrm{symptoms} \mathrm{of} \mathrm{the}$ peak resolution were recognized; a small negative peak was estimated to be a system peak. Accordingly, an 
oxalate mobile phase of $\mathrm{pH} 7$ was used thereafter.

\section{Ligand concentration}

Separations of the test analytes on a $100-\mathrm{mm}$ column using $0.005,0.0075$ and $0.01 \mathrm{~mol} \mathrm{dm}^{-3}$ oxalate mobile phases are shown in Fig. 4. The use of concentrated mobile phases significantly shortened the retention times, resulting in a sharpening of the peaks and an increasing of the peak heights. Thus, a $0.01 \mathrm{~mol} \mathrm{dm}^{-3}$ oxalate mobile phase was favored.

\section{Column length}

Separations of the test analytes on three columns of different lengths $(50,100,150 \mathrm{~mm} \times 4.6 \mathrm{~mm}$ i.d.) were investigated. In all cases, the separations were quite satisfactory. For an economy of time, a column $50-\mathrm{mm}$ long was chosen thereafter.

Optimal conditions for separating $\mathrm{Na}^{+}, \mathrm{K}^{+}, \mathrm{Mg}^{2+}$ and $\mathrm{Ca}^{2+}$ River water does not contain $\mathrm{Sr}^{2+}$ and $\mathrm{Ba}^{2+}$ to any

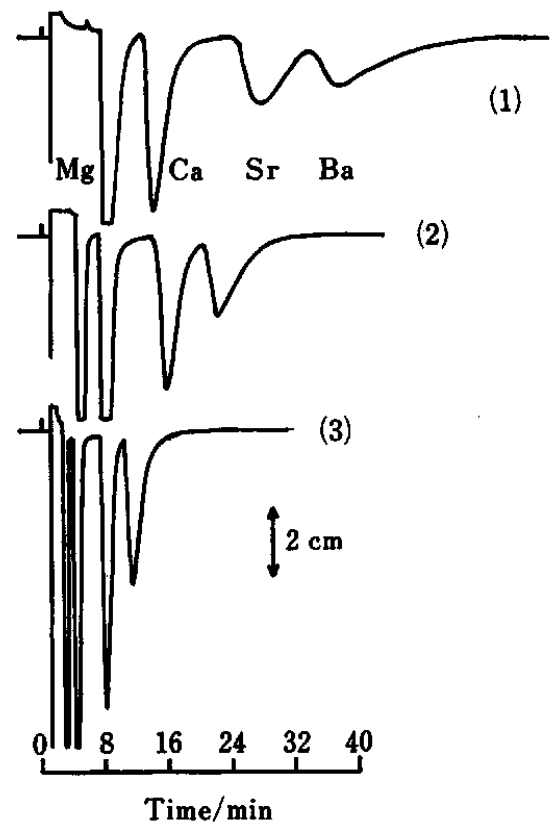

Fig. 4 Effect of the oxalate concentration on the retention times of the test analyte. (1) $5 \times 10^{-3} \mathrm{M}$; (2) $7.5 \times 10^{-3} \mathrm{M}$ and (3) $1 \times 10^{-2} \mathrm{M}$ oxalate solution; other conditions, see Fig. 1 . appreciable extent, but contains $\mathrm{Na}^{+}, \mathrm{K}^{+}, \mathrm{Mg}^{2+}$ and $\mathrm{Ca}^{2+}$ to a considerable extent. For water analysis, therefore, conditions such as mobile-phase concentrations, sample sizes and flow rates were reinvestigated. For a complete separation, a $2 \times 10^{-3} \mathrm{~mol} \mathrm{dm}^{-3}$ oxalate mobile phase, an injection of $200 \mu \mathrm{l}$ of water sample and a flow rate of $1.5 \mathrm{ml} \mathrm{min} \mathrm{m}^{-1}$ were found to be adequate; only $16 \mathrm{~min}$ was required for a single run.

\section{Calibration curves}

The integrator used can measure peak areas of either a negative or positive peak. Accordingly, water samples were always chromatographed twice under different polarity (i.e., $\mathrm{Na}^{+}$and $\mathrm{K}^{+}$under normal and $\mathrm{Mg}^{2+}$ and $\mathrm{Ca}^{2+}$ under reversed polarity). Plot of the peak areas vs. the analyte concentrations $\left(\mathrm{Na}^{+}\right.$and $\mathrm{Ca}^{2+}$ : $\left(0-10^{-3}\right) \mathrm{mol} \mathrm{dm}^{-3} ; \mathrm{K}^{+}$and $\left.\mathrm{Mg}^{2+}:\left(0-10^{-4}\right) \mathrm{mol} \mathrm{dm}^{-3}\right)$ gave good straight lines with correlation coefficients greater than 0.999 . The relative standard deviations for five runs were $0.59,1.6,0.85$ and $0.35 \%$ for $\mathrm{Na}^{+}, \mathrm{K}^{+}$, $\mathrm{Mg}^{2+}$ and $\mathrm{Ca}^{2+}$, respectively.

\section{Separation of $\mathrm{NH}_{4}^{+}$from $\mathrm{K}^{+}$}

The resolution between the $\mathrm{K}^{+}$and $\mathrm{NH}_{4}{ }^{+}$peaks was not satisfactory; for example, the coexistence of an equimolar amount of $\mathrm{NH}_{4}{ }^{+}$resulted in about a 20 percent positive error for potassium. Fortunately, nonpolluted river water ordinarily contains about $1 \mathrm{ppm}$ of $\mathrm{K}^{+}$and less than about $0.05 \mathrm{ppm}$ of $\mathrm{NH}_{4}{ }^{+}{ }^{20}$ Hence, the interference of $\mathrm{NH}_{4}{ }^{+}$was neglected.

\section{Application to river water}

Water samples collected from three major rivers in Okayama prefecture, Japan (the Asahi, the Yoshii and the Takahashi rivers) were filtered through a membrane filter (pore size $=0.22 \mu \mathrm{m}$, Millipore), bottled in a polyethylene vessel and stored in a refrigerator. Tap water (Table 3) has its own source in the Asahi river.

As an illustration, a chromatogram of water from the Asahi river is depicted in Fig. 5. The peak resolution is quite satisfactory. The concentrations of $\mathrm{Na}^{+}$and $\mathrm{K}^{+}$ were determined by means of atomic absorption spectroscopy (AAS). The total concentration of $\mathrm{Mg}^{2+}$ and $\mathrm{Ca}^{2+}$ was determined by means of an EDTA titration method. ${ }^{6}$

The proposed IC method gave concordant results

Table 3 Sodium, potassium, magnesium and calcium concentrations in river water

\begin{tabular}{|c|c|c|c|c|c|c|c|c|c|c|}
\hline \multirow[t]{2}{*}{ Water } & \multicolumn{2}{|c|}{$\mathrm{Na}^{+}$} & \multicolumn{2}{|c|}{$\mathbf{K}^{+}$} & \multicolumn{2}{|c|}{$\begin{array}{c}\text { Concentration, ppm } \\
\mathrm{Mg}^{2+}\end{array}$} & \multicolumn{2}{|c|}{$\mathrm{Ca}^{2+}$} & \multicolumn{2}{|c|}{$\mathrm{Mg}^{2+}+\mathrm{Ca}^{2+}$} \\
\hline & $\mathrm{IC}^{\mathrm{a}}$ & AAS & IC & AAS & IC & EDTA $^{b}$ & IC & EDTA & IC & EDTA \\
\hline Tap water & 6.32 & 5.9 & 1.3 & 1.1 & 1.79 & 1.9 & 7.62 & 7.74 & 9.41 & 9.6 \\
\hline Asahi river & 6.39 & 5.8 & 1.2 & 1.2 & 1.68 & 1.4 & 7.25 & 7.86 & 8.93 & 9.3 \\
\hline Takahashi river & 5.01 & 5.0 & 1.2 & 1.1 & 1.89 & 1.3 & 15.1 & 16.1 & 17.0 & 17.4 \\
\hline Yoshii river & 7.68 & 7.5 & 1.4 & 1.4 & 1.86 & 1.4 & 9.38 & 10.2 & 11.2 & 11.6 \\
\hline
\end{tabular}

a. Proposed method. b. EDTA titration method. 


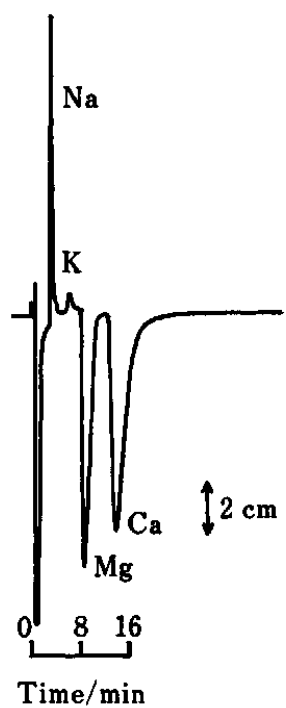

Fig. 5 A typical chromatogram obtained with river water. Sample size, $200 \mu \mathrm{l}$; flow rate, $1.5 \mathrm{ml} / \mathrm{min}$; mobile phase, $0.002 \mathrm{M}$ oxalate solution at $\mathrm{pH} 7$; column, $50 \mathrm{~mm} \times 4.6 \mathrm{~mm}$ i.d.; recorder, $5 \mathrm{mV} / 20 \mathrm{~cm}$ (FS).

with both the AAS and EDTA methods. For $\mathrm{Mg}^{2+}$, the proposed method gave slightly higher concentrations than the EDTA method, and vice versa for $\mathrm{Ca}^{2+}$. With regard to the $\mathrm{Mg}^{2+}+\mathrm{Ca}^{2+}$ concentration, however, both methods gave concordant results; these facts indicate that an incomplete masking of $\mathrm{Mg}^{2+}$ in the EDTA method resulted in increases in the $\mathrm{Ca}^{2+}$ concentrations.

\section{References}

1. K. K. Unger, "Porous Silica", in "J. Chromatogr. Lib.",
Elsevier, Amsterdam, 1979.

2. D. N. Strazhesko, V. B. Strelko, V. N. Belyakov and S. C. Rubanik, J. Chromatogr., 102, 191 (1974).

3. D. L. Dugger, J. J. Stanton, B. N. Irby, B. L. McConnel, W. W. Cummings and R. W. Maatmann, J. Phys. Chem., 68, 757 (1964).

4. R. L. Smith and D. J. Pietrzyk, Anal. Chem., 56, 610 (1984).

5. T. Iwachido, K. Ishimaru and S. Motomizu, Anal. Sci., 4, 81 (1988).

6. K. Ueno, "Kireto Tekiteiho (Chelate Titration Method, in Japanese)", p. 366, Nankodo, Tokyo, 1964.

7. M. L. Hair and W. Hertl, J. Phys. Chem., 74, 91 (1970).

8. T. Iwachido and N. Hayama, Anal. Sci., 6, 307 (1990).

9. R. A. Robinson and R. H. Stokes, "Electrolyte Solutions [2nd Ed. Revised]", p. 463, Butterworths, London, 1968.

10. C. F. Baes, Jr. and R. E. Mesmer, "The Hydrolysis of Cations", pp. 99 -103, John Wiley \& Sons, New York, 1976.

11. V. C. Vosburg and J. F. Beckman, J. Am. Chem. Soc., 62, 1028 (1940).

12. E. Gelles and G. H. Nancollas, J. Chem. Soc., 1956, 4847.

13. E. Campi, Amn. Chim., 53, 96 (1963).

14. G. D. Pinching and R. G. Bates, J. Res. Nat. Bur. Standard, 45, 322 (1950).

15. M. Eden and R. G. Bates, J. Res. Nat. Bur. Standard, 62, 161 (1959).

16. R. G. Bates and A. G. Canham, J. Res. Nat. Bur. Standard, 47, 343 (1951).

17. C. W. Davies, Trans. Faraday Soc., 23, 351 (1927).

18. R. W. Money and C. W. Davies, Trans. Faraday Soc., 28, 609 (1932).

19. R. K. Cannan and A. Kibrick, J. Am. Chem. Soc., 60, 2314 (1938).

20. T. Kuwaki, M. Akiba, M. Oshima and S. Motomizu, Bunseki Kagaku, 36, T81 (1987).

(Received December 16, 1989) (Accepted February 5, 1990) 